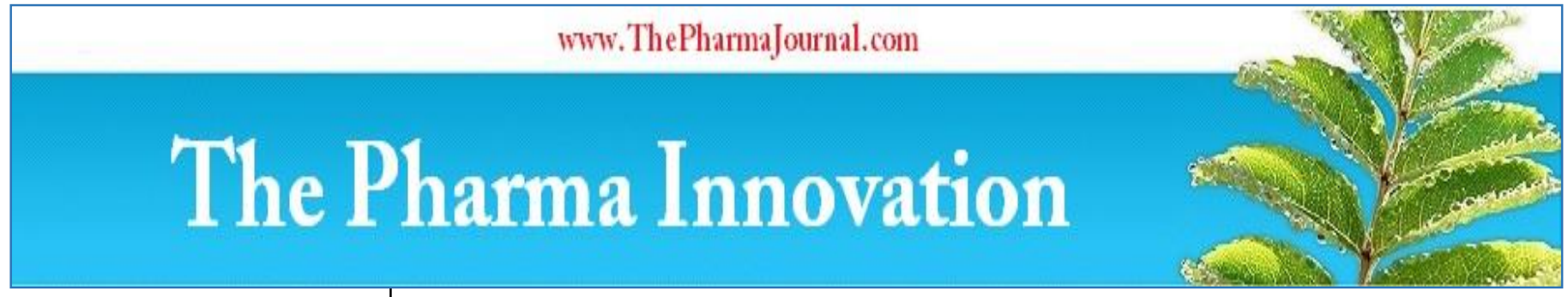

ISSN (E): 2277 - 7695

ISSN (P): 2349-8242

NAAS Rating: 5.23

TPI 2021; SP-10(6): 452-456

(C) $2021 \mathrm{TPI}$

www.thepharmajournal.com

Received: 22-04-2021

Accepted: 24-05-2021

Shyam Sundar Kesh

Department of Veterinary

Clinical Complex (Veterinary

Biochemistry), Faculty of

Veterinary and Animal Sciences,

West Bengal University of

Animal and Fishery Sciences,

Kolkata, West Bengal, India

Santwana Palai

Department of Veterinary

Pharmacology and Toxicology,

College of Veterinary Science and

Animal Husbandry, OUAT,

Bhubaneswar, Odisha, India

Swaraj Biswas

Department of Veterinary

Biochemistry, Faculty of

Veterinary and Animal Sciences,

West Bengal University of

Animal and Fishery Sciences,

Kolkata, West Bengal, India
Corresponding Author: Shyam Sundar Kesh Department of Veterinary Clinical Complex (Veterinary Biochemistry), Faculty of Veterinary and Animal Sciences, West Bengal University of Animal and Fishery Sciences, Kolkata, West Bengal, India

\section{Drugs contraindicated in cat}

\section{Shyam Sundar Kesh, Santwana Palai and Swaraj Biswas}

DOI: https://doi.org/10.22271/tpi.2021.v10.i6Sg.6689

\section{Abstract}

While medicating cats, veterinarians have to very cautious else they can face serious adverse effects. Cats are different from other animals with respect to metabolism. Various drugs like antibiotics, Non-steroidal anti-inflammatory drugs (NSAIDs), anti-parasitic etc. are causing adverse effects in cats. The prescribed drugs may cause acute poisoning even at therapeutic doses. This review aims at providing information to clinical veterinarian, pet owner to be cautious while administering of drugs in cats. The adverse effects of contraindicated drugs are summarised here for accurate use of drugs and to avoid acute poisoning leading to death.

Keywords: cat, toxicity, glucuronidation

\section{Introduction}

Drugs are the modern world medicines for diseases that animals suffer from. While medicating cats, drugs are to be given only after being advised by veterinarians. As the cat is already suffering, care is to be taken to see that it further does not succumb to drug toxicity. As cats are lacking many drug conjugation pathways, they cannot metabolise certain drugs as other animals leading to slow metabolism and excretion of those drugs causing toxicities and other side effects. So, alternate therapeutic regimen or adjustment of dose of those drugs can be prescribed. The most accepted conjugation defect is reduced glucuronidation of phenolic drugs, such as acetaminophen and propofol. The drugs elimination mechanisms like conjugation, oxidation in cat vary from other animals like dogs and humans, and thus are excreted unchanged into the urine and/or bile. Drugs like aspirin, acetaminophen, propofol requiring metabolic conjugation, like glucuronidation, sulfation, glycination occur slower in cats. On the other hand piroxicam is eliminated more speedily in cats as it is metabolised by oxidation. This review aims to enlist all the drugs contraindicated in cats along with their side effects which can be of help to doctors, veterinarians as well as cat owners.

\section{Mechanisms causing difference in metabolism in cats}

Cats lack UDP-glucuronosyltransferase (UGT) enzymes like UGT1A6 and UGT1A9 responsible for glucuronidation of these drugs in other species. So, Slower carprofen clearance results from deficient glucuronidation and slower aspirin clearance occurs due to poor glycine conjugation. Cats are also deficient in $\mathrm{N}$-acetyltransferase (NAT) enzymes specifically NAT2 which is responsible for $\mathrm{N}$-acetylation conjugation pathways resulting in acetaminopheninduced methemoglobinemia. The deficiency of thiopurine methyltransferase (TPMT) responsible for S-methylation results in azathioprine toxicity. Drugs that are eliminated by oxidation have no changed effect in cats. Piroxicam is cleared more rapidly in cats than other animals and humans. The intensity of drug binding to plasma protein may also result in differences in highly bound drugs pharmacokinetic ${ }^{[2]}$.

\section{Molecular basis for difference of metabolism in cats}

Since last few decades, this difference in metabolism and excretion of drugs in cats in comparison to other species has been studied. The deficiencies in 4 different types of drug elimination pathways are studied like

- Glucuronidation (UGTS)

- Acetylation (NATS)

- Methylation (Thiopurine methyltransferase [TPMT])

- Active transport (ATP-binding cassette G2 [ABCG2]) 


\section{Drugs contraindicated in Cat}

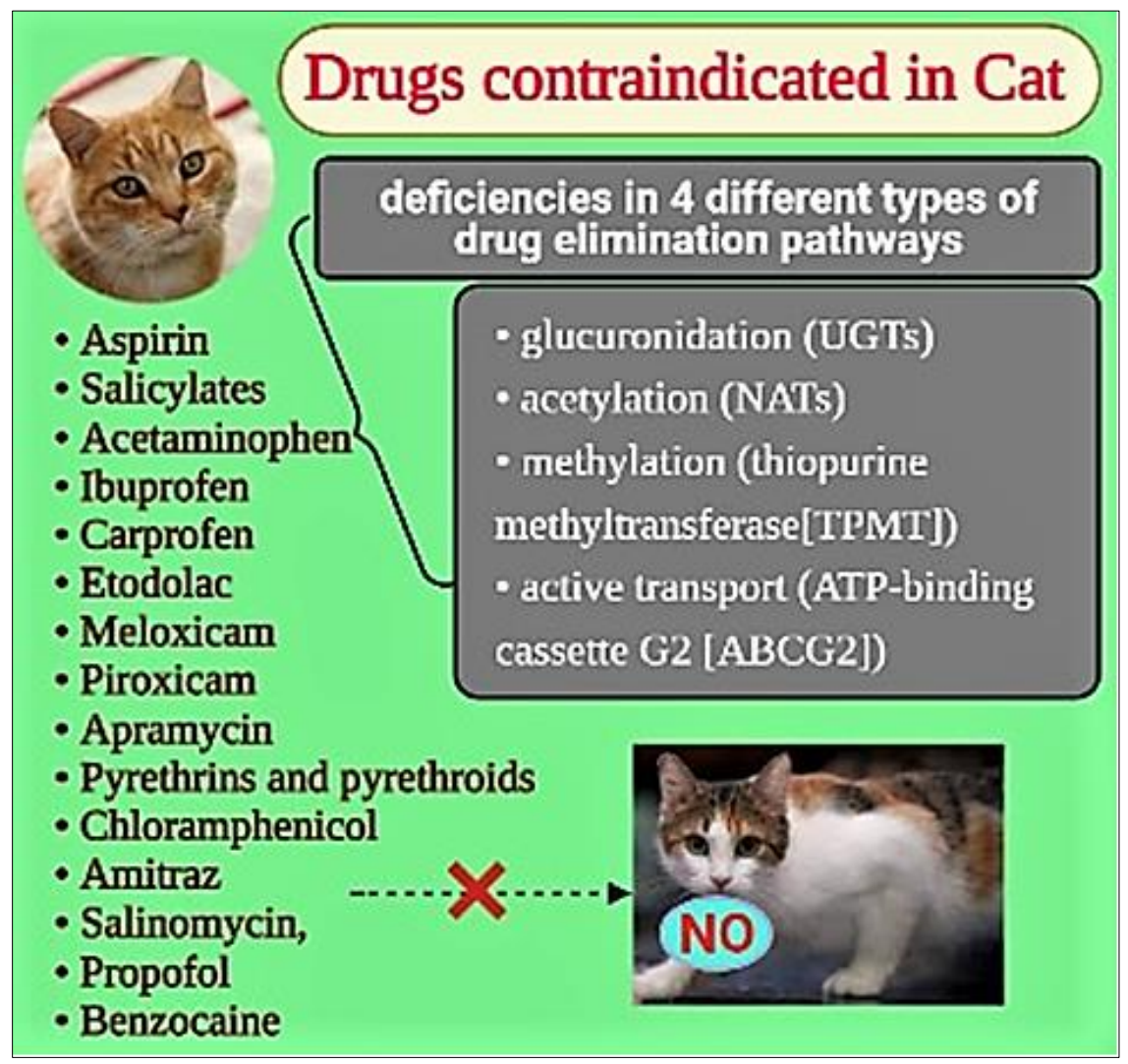

Fig 1: Drugs contraindicated in cats

Table 1: Drugs contraindicated in cats

\begin{tabular}{|c|c|c|c|c|c|c|}
\hline $\begin{array}{c}\text { Types of } \\
\text { drugs }\end{array}$ & $\begin{array}{c}\text { Name of the } \\
\text { drugs }\end{array}$ & Description & $\begin{array}{c}\text { Mechanism of } \\
\text { action }\end{array}$ & $\begin{array}{c}\text { Reason for } \\
\text { toxicity }\end{array}$ & Toxicity symptoms & $\begin{array}{c}\text { Referen } \\
\text { ces }\end{array}$ \\
\hline \multirow{3}{*}{ NSAIDs } & Aspirin & Salicylate and its salt & $\begin{array}{c}\text { Cyclooxygenase e } \\
\text { nzyme } \\
\text { inactivation } \\
\text { irreversibly leads } \\
\text { to suppression of } \\
\text { the } \\
\text { thromboxanes \& } \\
\text { prostaglandins. }\end{array}$ & $\begin{array}{c}\text { Less of } \\
\text { glucuronyl } \\
\text { transferase and } \\
\text { glycine } \\
\text { conjugation }\end{array}$ & $\begin{array}{l}\text { Increased bleeding } \\
\text { time, fever, vomiting } \\
\text { with blood, panting, } \\
\text { liver damage, coma, } \\
\text { seizures, death. }\end{array}$ & [1] \\
\hline & Salicylates & $\begin{array}{l}\text { Salt or ester of } \\
\text { salicylic acid, food } \\
\text { preservatives, } \\
\text { antiseptics, } \\
\text { acteriostatic, } \\
\text { fungicidal keratolytic }\end{array}$ & $\begin{array}{l}\text { Nonselective } \\
\text { inhibition of } \\
\text { peripherally and } \\
\text { centrally mediated } \\
\text { cyclooxygenase. } \\
\text { Potent inhibitor of } \\
\text { thromboxane } \\
\text { production } \\
\text { function. }\end{array}$ & $\begin{array}{l}\text { Relatively } \\
\text { deficient in } \\
\text { glucuronosyl } \\
\text { transferase, which } \\
\text { conjugates } \\
\text { salicylate with } \\
\text { glucuronic acid. }\end{array}$ & $\begin{array}{c}\text { Lethargy, vomiting, } \\
\text { diarrhoea, } \\
\text { hematemesis, } \\
\text { melena, abdominal } \\
\text { pain, asthma, } \\
\text { headaches, nasal } \\
\text { congestion, } \\
\text { itching, skin rash, } \\
\text { or hives, Swelling of } \\
\text { the hands, feet, and } \\
\text { face, Stomach pain } \\
\text { Severe gastric } \\
\text { ulceration. } \\
\end{array}$ & [2] \\
\hline & $\begin{array}{l}\text { Acetaminophen } \\
\text { (Paracetamol) }\end{array}$ & $\begin{array}{l}\text { Aniline } \\
\text { analgesics }\end{array}$ & $\begin{array}{l}\text { Prostaglandin's } \\
\text { synthesis is } \\
\text { weakly inhibited } \\
\text { like selective } \\
\text { cyclooxygenase-2 } \\
\text { inhibitors and also } \\
\text { decreased } \\
\text { concentration of } \\
\text { prostaglandins. }\end{array}$ & $\begin{array}{c}\text { Deficient in } \\
\text { glucuronidation } \\
\text { and sulfation } \\
\text { abilities, N-acetyl- } \\
\text { p- } \\
\text { benzoquinoneimin } \\
\text { e (NAPQI) } \\
\text { formed } \\
\text { alternatively bind } \\
\text { and damage the } \\
\text { hepatic cell } \\
\text { membrane leading } \\
\text { to its injury and } \\
\text { death }\end{array}$ & $\begin{array}{c}\text { Depression, } \\
\text { weakness, cyanosis, } \\
\text { vomiting, tachypnea, } \\
\text { facial edema, paw } \\
\text { edema, dyspnea, } \\
\text { Heinz body anaemia, } \\
\text { methemoglobinemia } \\
\text { (muddy or brown } \\
\text { mucous membrane), } \\
\text { hepatotoxicity, } \\
\text { nephrotoxicity, } \\
\text { death. }\end{array}$ & [3] \\
\hline
\end{tabular}




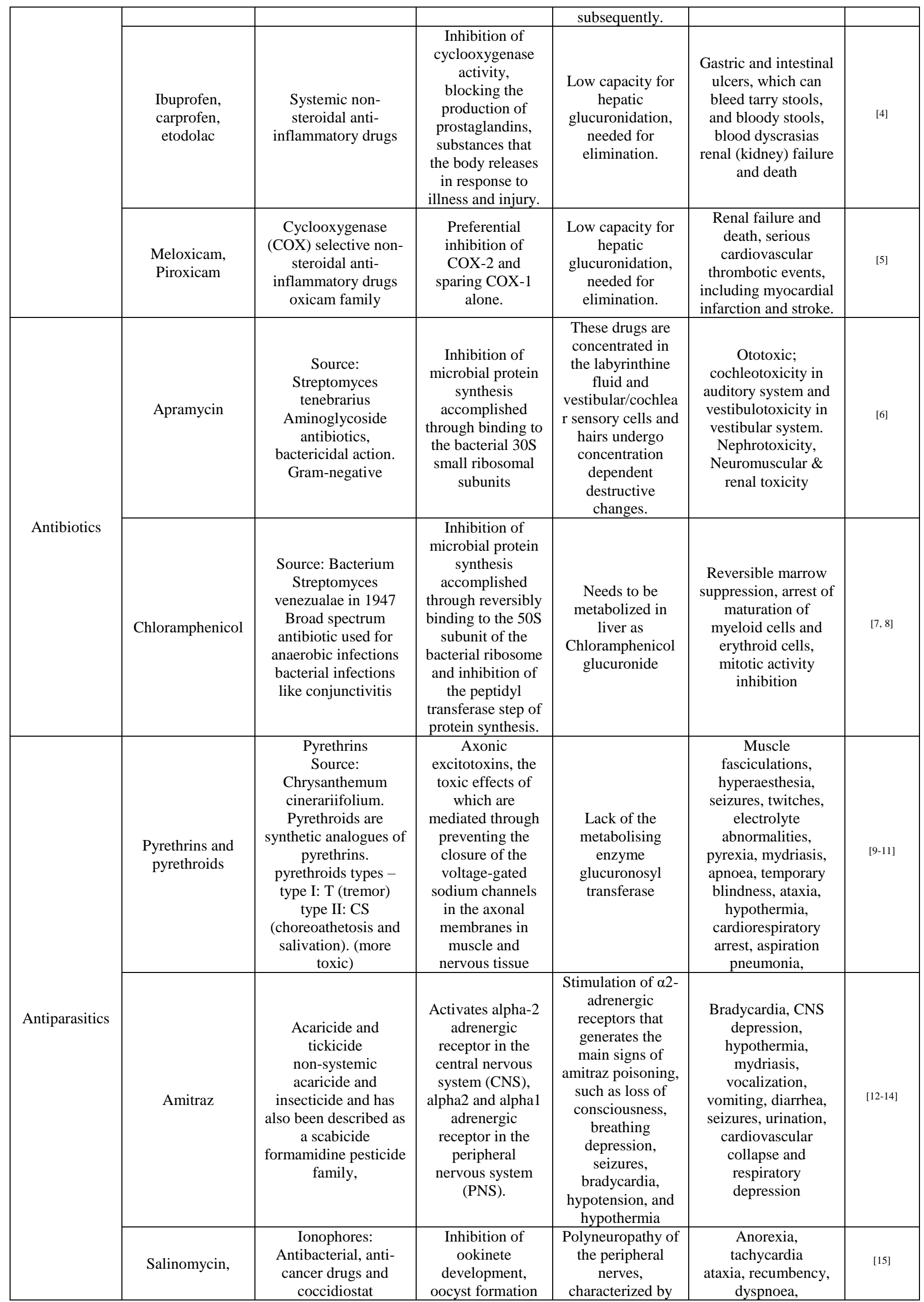




\begin{tabular}{|c|c|c|c|c|c|c|}
\hline & & & $\begin{array}{l}\text { in the mosquito } \\
\text { midgut, blocking } \\
\text { their transmission } \\
\text { Selectively } \\
\text { damages infected } \\
\text { erythrocytes. }\end{array}$ & $\begin{array}{l}\text { primary axonal } \\
\text { degeneration and } \\
\text { secondary } \\
\text { degeneration of } \\
\text { the myelin sheath } \\
\text { resulting in } \\
\text { paralysis. } \\
\text { hypoxia of the } \\
\text { myocardium due } \\
\text { to dyspnoea from } \\
\text { paralysis of the } \\
\text { respiratory } \\
\text { musculature }\end{array}$ & $\begin{array}{c}\text { peripheral } \\
\text { polyneuropathy, } \\
\text { paresis and paralysis }\end{array}$ & \\
\hline \multirow[t]{2}{*}{ Anesthetics } & Benzocaine & $\begin{array}{l}\text { Topical local } \\
\text { anesthetics }\end{array}$ & $\begin{array}{c}\text { Stabilizes the } \\
\text { neuronal } \\
\text { membrane } \\
\text { reversibly, } \\
\text { decreasing its } \\
\text { permeability to } \\
\text { sodium ions, } \\
\text { inhibition of } \\
\text { depolarization of } \\
\text { the neuronal } \\
\text { membrane } \\
\text { blocking of } \\
\text { initiation and } \\
\text { conduction of } \\
\text { nerve impulses. }\end{array}$ & $\begin{array}{l}\text { Due to their } \\
\text { unique } \\
\text { hemoglobin } \\
\text { structure, it is } \\
\text { easily damaged }\end{array}$ & $\begin{array}{l}\text { Seizures, tremors and } \\
\text { cardiac arrhythmia, } \\
\text { Heinz body } \\
\text { formation, } \\
\text { methemoglobinemia } \\
\text { reduced oxygen } \\
\text { carrying capacity, } \\
\text { hemolytic anemia. }\end{array}$ & [16] \\
\hline & Propofol & $\begin{array}{l}\text { Intravenous general } \\
\text { anaesthetic }\end{array}$ & $\begin{array}{c}\text { Decreases the rate } \\
\text { of dissociation of } \\
\text { the Gamma- } \\
\text { aminobutyric acid } \\
\text { (GABA) from the } \\
\text { receptor, duration } \\
\text { of the GABA- } \\
\text { activated opening } \\
\text { of the chloride } \\
\text { channel increased } \\
\text { resulting } \\
\text { hyperpolarization } \\
\text { of cell } \\
\text { membranes. }\end{array}$ & $\begin{array}{l}\text { Lack of } \\
\text { glucuronosyl } \\
\text { transferase which } \\
\text { is needed to } \\
\text { glucuronidate } \\
\text { propofol. }\end{array}$ & $\begin{array}{l}\text { Metabolic acidosis, } \\
\text { bradyarrhythmias, } \\
\text { and progressive } \\
\text { myocardial failure, } \\
\text { Heinz body anemia }\end{array}$ & [17] \\
\hline
\end{tabular}

\section{UGT deficiency}

Glucuronidation is the most important process of metabolism which transfers glucuronic acid to a variety of drugs, toxins, steroids and bilirubuin like endogenous compounds thus promoting better elimination of these compounds into urine and/or bile. The main sites of drug metabolism like liver, kidney, intestinal mucosa express UGT.

The oldest broadly accepted idiosyncrasy of cat is deficient glucuronidation. Literatures as old as 60 years show inability of cat to glucuronidate drugs and toxins ${ }^{[18]}$. This deficiency in cat is not specific to all glucuronidated drugs but depends on structure of drug. It affects the simple planar phenolic structured drugs which are to be mainly metabolized by UGT1A1, essential for glucuronidation and clearance of bilirubin. UGT1A isoforms like UGT1A6 and UGT1A9 particularly found in liver. 10 different UGT1As are expressed in dogs liver, 9 different UGT1As are expressed in human liver but feline liver have only 2 isoforms (UGT1A1 and UGT1A2) and the UGT1A6 pseudogene. No UGT1A isoform related to UGT1A6 or UGT1A9 was expressed in cat liver.

UGT1A6 gene identification by DNA sequencing proved multiple mutations suggesting a functional UGT1A6 gene present at one point in cats that had been permanently disabled in cat into a pseudogene ${ }^{[19]}$. Carnivore species
(African lion, cheetah, leopard, tiger, leopard, margay, tigrina, lynx, golden cat, bobcat, puma, Florida panther, cat) showed UGT1A6 mutations which evolved them differently them from Carnivora species (wolves, bears, raccoon, ferret) between 11 and 35 million years ago.

Drug like morphine is selectively glucuronidated in humans by UGT2B7 gene. Although Cats express feline orthologs of human UGT2B7 and UGT2B15, it shows reduced morphine glucuronidation which gets compensated by sulfation pathways clearance.

Drug like lorazepam is selectively glucuronidated in humans by UGT2B15 gene but it is glucuronidated speedily in cats as feline ortholog of human UGT2B15 is expressed in cats ${ }^{[20]}$.

Preservative like benzoic acid and Benzyl alcohol (is metabolized to benzoic acid) and excreted as the glucuronide or glycine conjugate in most species. Cats are unable to glucuronidate benzoic acid, but can glycinate it slowly. So, benzyl alcohol used in pharmaceutical preparations for cats are minimized.

\section{Glycine deficiency}

Drugs like aspirin have slow clearance in cats due to poor glycine conjugation. 


\section{NAT2 Deficiency}

Drugs like isoniazid, many of the sulfonamide antibiotics like sulfamethazine, sulfanilamide, sulfadimethoxine, dapsone, hydralazine, procainamide, acetaminophen need to be acetylated for metabolism. N-Acetylation is catalyzed by the $\mathrm{N}$-acetyltransferase enzymes NAT1 and NAT2. Cats liver lack NAT2, but express NAT1, thus show lower enzyme activity than other species ${ }^{[21]}$. So, these drugs are acetylated more slowly in cats showing toxicities in cats.

\section{TPMT deficiency}

Drugs like 6-mercaptopurine for cancer and azathioprine for immunosuppression require S-Methylation by TPMT for metabolism and excretion. Less TPMT activity in cat erythrocytes involving gene sequence differences affect enzyme level and affinity for substrate and activity ${ }^{[22]}$.

\section{ABCG2 deficiency}

Drugs like Fluoroquinolone antibiotic use ABCG2 transporter for efflux. Due to inefficient efflux by ABCG2 transporter from the feline eye, temporary and subsequently permanent blindness develop in cats ${ }^{[23]}$.

\section{Conclusion}

Further molecular level studies are needed to understand the differences in cats in drug metabolism and disposition. It will help in more rational prescribing of prevailing medications, and effective and safer drugs discovery and development for cats. Pet owners of cats should be made aware to avoid these medications either intentionally or accidentally.

\section{References}

1. Shrestha B, Reed JM, Starks PT, Kaufman GE, Goldstone JV, Roelke ME et al. Evolution of a major drug metabolizing enzyme defect in the domestic cat and other felidae: phylogenetic timing and the role of hypercarnivory. PloS one 2011;6(3):e18046.

2. Court MH. Feline drug metabolism and disposition: pharmacokinetic evidence for species differences and molecular mechanisms. The Veterinary Clinics of North America. Small Animal Practice 2013;43(5).

3. Hinz B, Cheremina O, Brune K. Acetaminophen (paracetamol) is a selective cyclooxygenase-2 inhibitor in man. The FASEB journal 2008;22(2):383-90.

4. Rao GH, Johnson GG, Reddy KR, White JG. Ibuprofen protects platelet cyclooxygenase from irreversible inhibition by aspirin. Arteriosclerosis: An Official Journal of the American Heart Association, Inc $1983 ; 3(4): 383-8$.

5. Lascelles BD, Court MH, Hardie EM, Robertson SA. Non-steroidal anti-inflammatory drugs in cats: a review. Veterinary anaesthesia and analgesia 2007;34(4):228-50.

6. Oishi N, Talaska AE, Schacht J. Ototoxicity in dogs and cats. Veterinary Clinics: Small Animal Practice 2012;42(6):1259-71.

7. Watson AD, Middleton DJ. Chloramphenicol toxicosis in cats. American journal of veterinary research 1978;39(7):1199-203.

8. Shukla P, Bansode FW, Singh RK. Chloramphenicol toxicity: A review. Journal of Medicine and Medical Sciences 2011;2(13):1313-6.

9. Sutton NM, Bates N, Campbell A. Clinical effects and outcome of feline permethrin spot-on poisonings reported to the Veterinary Poisons Information Service (VPIS),
London. Journal of Feline Medicine and Surgery 2007;9(4):335-9.

10. Boland LA, Angles JM. Feline permethrin toxicity: retrospective study of 42 cases. Journal of feline medicine and surgery 2010;12(2):61-71.

11. Anadón A, Martínez-Larrañaga MR, Martínez MA. Use and abuse of pyrethrins and synthetic pyrethroids in veterinary medicine. The Veterinary Journal 2009;182(1):7-20.

12. Andrade SF, Sakate M, Laposy CB, Valente SF, Bettanim VM, Rodrigues LT et al. Effects of experimental amitraz intoxication in cats. Arquivo Brasileiro de Medicina Veterinária e Zootecnia 2007;59(5):1236-44.

13. Plumb DC. (Ed.) Veterinary Drug Handbook, 3 ed., Iowa State University Press, Ames 1999, 750.

14. do Monte Barretto ML, de Deus Ferreira A, Pascoal IC, da Silva MB, de Torres SM, Falcão MV et al. Amitraz: pharmacological and toxicological aspects in animals. Medicina Veterinária (UFRPE) 2017;11(3):185-91.

15. Van der Linde-Sipman JS, Van Den Ingh TS, Van Nes JJ, Verhagen H, Kersten JG, Beynen AC et al. Salinomycininduced polyneuropathy in cats: morphologic and epidemiologic data. Veterinary pathology 1999;36(2):152-6.

16. Patrascu J, Bedreag O, Papurica M, Biris M, Ancusa O, Onetiu D et al. Compatibility of ester-type anesthetic agents with two polysaccharides. Rev Chim 2014;65(8):921-4.

17. Takahashi H, Maruo $\mathrm{Y}$, Mori A, Iwai M, Sato H, Takeuchi Y. Effect of D256N and Y483D on propofol glucuronidation by human uridine 5'-diphosphate glucuronosyltransferase (UGT1A9). Basic \& clinical pharmacology \& toxicology 2008;103(2):131-6.

18. Hartiala KJ. Studies on detoxication mechanisms. III. Glucuronide synthesis of various organs with special reference to the detoxifying capacity of the mucous membrane of the alimentary canal. In Annales medicinae experimentalis et biologiae Fenniae 1955;33(3):239-245.

19. Greenblatt DJ. Molecular genetic basis for deficient acetaminophen glucuronidation by cats: UGT1A6 is a pseudogene, and evidence for reduced diversity of expressed hepatic UGT1A isoforms. Pharmacogenetics and Genomics 2000;10(4):355-69.

20. Schillings RT, Sisenwine SF, Schwartz MH, Ruelius HW. Lorazepam: Glucuronide formation in the cat. Drug Metabolism and Disposition 1975;3(2):85-8.

21. Trepanier LA, Cribb AE, Spielberg SP, Ray K. Deficiency of cytosolic arylamine $\mathrm{N}$-acetylation in the domestic cat and wild felids caused by the presence of a single NAT1-like gene. Pharmacogenetics 1998;8(2):169-79.

22. Salavaggione OE, Yang C, Kidd LB, Thomae BA, Pankratz VS, Trepanier LA et al. Cat red blood cell thiopurine S-methyltransferase: companion animal pharmacogenetics. Journal of Pharmacology and Experimental Therapeutics 2004;308(2):617-26.

23. Ramirez CJ, Minch JD, Gay JM, Lahmers SM, Guerra DJ, Haldorson GJ et al. Molecular genetic basis for fluoroquinolone-induced retinal degeneration in cats. Pharmacogenetics and genomics 2011;21(2):66-75. 